\title{
Perubahan Perkembangan Dalam Hukum Perdata Modern
}

\author{
Abdurrahman Konoras (abdurahman_konoras@yahoo.co.id) \\ Fakultas Hukum Universitas Sam Ratulangi Manado
}

\begin{abstract}
Changes in legal development occur because the law and society are dynamic. Changes in the private law have implications for the strengthening of internal control functions that replace external control functions. Developmental changes in the modern private law are closely related to the changing societies and ruling regimes, which strengthen the role and participation of the people on the one hand, and the diminishing role of the state on the other is inseparable from modernization and democratization within the state and society itself. The contract law, labor law, and consumer protection law are subject to changes arising from the strengthening of internal control functions that replace external control functions.
\end{abstract}

Keywords: Change, Development, Private Law.

\begin{abstract}
ABSTRAK
Perubahan perkembangan hukum terjadi karena hukum dan masyarakat itu dinamis. Perubahan dalam Hukum Privat berimplikasi terhadap penguatan fungsi kontrol internal yang menggantikan fungsi kontrol eksternal. Perubahan perkembangan dalam Hukum Privat/Perdata modern berkaitan erat dengan perubahan masyarakat dan rezim yang berkuasa, yang semakin menguatnya peran dan partisipasi masyarakat di satu pihak, dan berkurangnya peran negara di lain pihak adalah tidak terlepas dari modernisasi dan demokratisasi dalam negara dan masyarakat itu sendiri. Hukum Kontrak Perjanjian, Hukum Tenaga Kerja, dan Hukum Perlindungan Konsumen mengalami perubahan yang terwujud dari menguatnya fungsi kontrol internal yang menggantikan fungsi kontrol dari luar.
\end{abstract}

Kata Kunci : Perubahan, Perkembangan, Hukum Privat. 


\section{PENDAHULUAN}

Hukum Perjanjian/Hukum Kontrak, Hukum Tenaga Kerja, dan Hukum Perlindungan Konsumen merupakan bagian-bagian dalam Hukum Perdata modern di suatu negara. Perkembangan dan perubahannya berkaitan erat dengan unsur substansif dan refleksif dalam hukum modern yang tidak lepas dari kondisi pemerintahan dan hukum suatu negara.

Peraturan perundang-undangan yang memuat dan mengatur berbagai hal mengenai hukum modern sebagai unsur substansif, tidak hanya tersedia dan berlaku, akan tetapi bagaimana dapat mengatur dan ditaati oleh masyarakat dalam suatu negara. Hal ini tidak hanya berkaitan dengan unsur substansif melainkan juga dengan prosedural pembentukan atau pembuatannya.

Satjipto Rahardjo (2006), mengemukakan, mekanisme yang digunakan oleh hukum untuk mengatur adalah dengan membuat dan mengeluarkan peraturan hukum, dan kemudian menerapkan sanksi terhadap para anggota masyarakat berdasarkan peraturan yang telah dibuat itu. Mekanisme yang demikian menyebabkan bahwa hukum pertamatama mengeluarkan peraturan yang berisi tentang perbuatan apa saja yang boleh dan tidak boleh dilakukan. Peraturan yang demikian itu disebut substantif.

Hukum Perjanjian, Hukum Tenaga Kerja, dan Hukum Perlindungan Konsumen adalah bagian-bagian dan unsur-unsur penting dalam hukum modern yang tidak dapat dipersamakan pembentukan dan penegakannya di antara negara-negara. Semakin maju dan demokratis suatu negara, semakin nyata unsur refleksif dalam hukumnya yang menampung dan memperjuangkan kepentingan-kepentingan dari warga negaranya.

Gambaran sebagai latar belakang masalah ini menunjukkan, perkembangan dalam Hukum Perjanjian, Hukum Tenaga Kerja, dan Hukum Perlindungan Konsumen terjadi dalam lingkungan Hukum Privat/Perdata modern.

\section{PERKEMBANGAN DALAM HUKUM PRIVAT/PERDATA MODERN}

Terbentuknya negara-negara baru belum berarti pula terbentuknya hukum baru yang modern, karena negara baru tidak identik pula dengan hukum baru/modern, yang 
perkembangannya dipengaruhi oleh rezim yang berkuasa dan yang memerintah sekaligus yang memiliki otoritas di dalam pembentukan hukum modern tersebut.

Bagaimana hukum yang dibentuk oleh suatu rezim, apakah memenuhi tipe tatanan hukum represif, hukum otonom, atau hukum responsif sebagaimana dirumuskan oleh Philippe Nonet dan Philip. Selznick dalam Ni'matul Huda (2005), tampak, apabila rezim yang otoriter hanya menghasilkan produk hukum yang represif. Perkembangan perubahan hukum ketika berkurangnya otoritarianisme ialah hukum menjadi lebih otonom dan responsif.

Perubahan perkembangan hukum dalam negara-negara modern terus terjadi, apabila telah memasuki tatanan hukum otonom dan responsif. Ni'matul Huda (2005), selanjutnya mengemukakan, di dalam masyarakat demokratis yang mendayagunakan hukum yang responsif dan otonom, karakteristik hubungan hukum dan kehidupan sosial berusaha digeser, legitimasi dan kompetensi menjadi menonjol; kejujuran prosedural dan keadilan substansif mulai dibicarakan; pendekatan hukum bersifat sistemik, mengacu pada asas dan kebijakan yang terpadu; pendekatan sosial dalam hukum (yuridis sosiologis) dilakukan; diskresi berorientasi pada tujuan; moralitas sipil membatasi kekuasaan negara; dan terjadi integrasi antara aspirasi hukum dan politik.

Hukum dalam suatu negara dan suatu masyarakat itu dipengaruhi oleh perkembangan dan perubahan-perubahan yang berlangsung terus menerus dalam masyarakat (Syahrani, 2004). Perubahan dalam masyarakat ikut pula berpengaruh terhadap hukum apabila rezim yang berkuasa di suatu negara itu merespons perubahan dan menerimanya sebagai sesuatu hal yang pantas untuk diterapkan melalui peraturan hukum.

Mochtar Kusumaatmadja dalam Otje Salman dan Eddy Damian (2006), mengemukakan, dalam suatu masyarakat yang sedang dalam peralihan dari suatu masyarakat yang tertutup, statis dan terbelakang ke suatu masyarakat yang terbuka, dinamis, maju (modern), nilai-nilai dalam masyarakat pun sedang dalam perubahan.

Hukum modern yang berpangkal dari dinamika hukum karena hukum dan masyarakat itu sendiri berkembang, yang berarti ada perubahan-perubahan tertentu. 
Menurut Satjipto Rahardjo (2006), hukum sebagaimana diterima dan dijalankan di negara-negara di dunia sekarang ini pada umumnya termasuk ke dalam kategori hukum modern. Modernitas ini mempunyai ciri-ciri sebagai berikut :

a. Mempunyai bentuk tertulis.

b. Hukum itu berlaku untuk seluruh wilayah negara.

Apabila kita memperhatikan sejarah, maka keadaannya tidak selalu demikian. Pada masa-masa yang lalu, di dalam suatu wilayah negara bisa berlaku berbagai macam hukum dengan otoritas yang bersaing, seperti dikatakan oleh Marc Galanter, hukum modern sekarang ini terdiri dari peraturan-peraturan yang bersifat uniform serta diterapkan tanpa mengenal variasi.

c. Hukum merupakan instrumen yang dipakai secara sadar untuk mewujudkan keputusankeputusan politik masyarakatnya.

Perkembangan masyarakat dan hukum dalam suatu negara tidak terlepas dari penguasa di negara itu sendiri. Dalam hal penguasanya cenderung diktator dan otoriter, hukumnya pun tampak cenderung represif dan hanya untuk diabdikan untuk kepentingan penguasa yang otoriter tersebut. Perkembangan dengan penguasa yang semakin demokratis menghasilkan hukum yang demokratis pula, dan pada konteks inilah hukum dan konstitusi menjadi landasan penting.

Pada bagian Iainnya, Satjipto Rahardjo (2006), menjelaskan bahwa suatu karakteristik yang menonjol dari kehidupan konstitusional yang demikian itu adalah terdapatnya suatu sistem peraturan hukum yang menjadi kerangka bagi seluruh kegiatan dalam suatu negara, baik itu kegiatan perorangan maupun kegiatan kenegaraan.

Adanya konstitusi yang dipandang sebagai hukum tertinggi dalam suatu negara, merupakan ciri dari suatu negara dan hukum yang modern. Konstitusi. Pemerintahan atau rezim yang konstitusional berarti di negara itu terdapat d suatu konstitusi (Undang-undang Dasar) yang menjadi dasar bagi kehidupan bermasyarakat, berbangsa, dan bernegara. Pemerintahan dalam negara yang seperti ini menampakkan ciri negara yang demokratis yang berbeda dari negara yang hukumnya represif. 
Ni'matul Huda (2005), menjelaskan, ciri khas dari demokrasi konstitusional ialah gagasan bahwa pemerintahan yang demokratis adalah pemerintahan yang terbatas kekuasaannya dan tidak dibenarkan bertindak sewenang-wenang terhadap warga negaranya. Kekuasaan negara dibagi sedemikian rupa sehingga kesempatan penyalahgunaan kekuasaan diperkecil.

Dalam rangka inilah, masyarakat atau warga negara ikut menentukan jalannya negara karena dilindungi oleh hukum. Hak-hak warga negara tidak dapat dikurangi atau dihilangkan begitu saja oleh negara, karena konstitusi memberikan jaminan yang tegas terhadap hakhak dari warga negaranya. Ciri hukum modem yang bertumpu pada konstitusi ini merupakan kenyataan yang umum di dalam negara-negara modern sekarang ini.

Hukum modern dengan konstitusional yang produk hukumnya memuat unsur substansif yang menjamin hak-hak warga negaranya, termasuk dalam hak-hak keperdataan dapat ditemukan dalam produkproduk hukum keperdataan yang pada dasarnya merupakan turunan (derivatif) dari ketentuan konstitusional, tampak misalnya hak-hak warga negara yang dijamin atau dilindungi oleh hukum misalnya dalam Hukum Perlindungan Konsumen.

Apabila selama ini Hukum Perlindungan Konsumen sudah jelas kurang berpihak terhadap kepentingan konsumen, maka kepentingan konsumen pun diatur dalam hukum dan pada giliran akhirnya unsur substansif dalam hukum mencerminkan adanya perlindungan hukum terhadap masyarakat selaku konsumen.

Contoh seperti ini menunjukkan keberpihakan hukum yang notabene merupakan keberpihakan negara terhadap kepentingan konsumen, sekaligus memberikan batas-batas dan mengaturnya sedemikian rupa sehingga pihak produsen atau pelaku usaha juga akan mengetahui ruang lingkup pengatur-an hukum yang menjadi kewajibannya.

\section{HUKUM PERJANJIAN, HUKUM TENAGA KERJA DAN HUKUM PERLINDUNGAN KONSUMEN DALAM PERKEMBENGANNYA}

Teubner mengkaji perubahan perkembangan dalam Hukum Privat/Perdata modern mengenai Hukum Perjanjian, Hukum Tenaga Kerja dan Hukum Perlindungan Konsumen, 
bahwa dalam Hukum Perjanjian/Kontrak terdapat kecenderungan rasionalitas hukum substansif yang jelas dalam rumusan pembentuk hukum/undang-undang tentang kondisi minimal dan keterlibatan judisial dalam substansi perjanjian.

Berbeda dari Hukum Tenaga Kerja dan Hukum Perlindungan Konsumen yang bercirikan suatu teknik pengawasan yang dapat mengenai potensi refleksif, karena kepentingan dan aspirasi pekerja serta kepentingan dan aspirasi konsumen turut melingkupi substansi hukumnya.

Dalam hal ini, posisi tawar-menawar antara buruh dan serikat buruh dengan pengusaha maupun penguasa, turut diperhatikan sehingga menempatkan perhatian terhadap kepentingan atau aspirasi pihak lainnya, yang dalam hal ini buruh maupun serikat pekerja. Demikian pula dalam kepentingan dan aspirasi konsumen berkenaan dengan Hukum Perlindungan Konsumen, yang dalam hal ini, hak-hak konsumen menjadi bahan perhatian penting.

Potensi refleksif dalam Hukum Tenaga Kerja misalnya, tampak dari dibukanya perundingan atau tawar-menawar di antara pekerja dan serikat pekerja/buruh pada satu pihak dan pengusaha serta penguasa/ pemerintah pada lain pihak termasuk dalam pembentukan hukum substansif. Aturan hukum tentang perundingan kolektif beroperasi terutama dengan membentuk organisasi perundingan/tawar menawar kolektif, merumuskan norma-norma prosedural, dan lain sebagainya.

Unsur refleksif yang terangkat misalnya dalam Hukum Tenaga Kerja dan Hukum Perlindungan Konsumen, ialah di dalam substansi hukum tersebut terakomodasi aspirasi dan kepentingan pihak lain, balk pekerja dan serikat pekerja maupun konsumen itu sendiri.

Dalam perlindungan konsumen peran lembaga baru yang bersifat semi-publik yang otonom dapat memberikan informasi bagi kepentingan konsumen. Dengan demikian, peran hukum di suatu negara bukanlah aturan substansif, tetapi prosedural dan struktur organisasi lainnya yang otonom. Sedangkan dalam Hukum Perjanjian, hubungan antara para pihak menentukan terjalinnya perjanjian atau kontrak itu sendiri, termasuk di dalamnya kebebasan berkontrak. 
Meuwissen dalam B. Arief Sidharta (2007), menjelaskan, apa yang dinamakan kebebasan berkontrak adalah juga merupakan suatu fundamen dari hukum perdata, dan tidak dapat disangkal bahwa is berasal dari periode kapitalistik awal dan berdasarkan itu di samping memiliki konsekuensi positif, juga banyak konsekuensi negatif. Karena itu dapat juga dimengerti bahwa dalam perkembangannya kemudian timbul nuansa-nuansa pada hukum kontrak (misalnya ajaran kepercayaan, 'undue influence', dan sebagainya). Kebebasan untuk menutup kontrak (pacta suet servanda) adalah suatu hal lain.

Kebebasan berkontrak atau kebebasan membuat suatu perjanjian yang sebenarnya berkaitan erat dengan Hukum Tenaga Kerja dan Hukum Perlindungan Konsumen, oleh karena dalam ketenagakerjaan dan perlindungan konsumen juga ada beberapa atau para pihak yang membuat kontrak atau perjanjian, yang menurut Feenstra dan Ahsmann dalam Ibrahim dan Sewu (2004), dikemukakan bahwa kebebasan berkontrak dapat ditinjau dari dua sudut, yaitu dalam arti materiil dan formil. Pertama, kebebasan berkontrak dalam arti materiil adalah bahwa diberikan kesepakatan atau persetujuan terhadap setiap isi atau substansi yang dikehendaki. Pembatasan-pembatasan terhadap persetujuan hanya dalam bentuk ketentuanketentuan umum, yang mensyaratkan bahwa isi tersebut harus merupakan sesuatu yang halal dan menerapkan bentuk aturan-aturan khusus, berupa hukum memaksa bagi jenis-jenis perjanjianperjanjian tertentu misalnya perjanjian ketenagakerjaan dan sews menyewa. Kebebasan berkontrak dalam arti materiil dikenal dengan sistem terbuka perjanjianperjanjian.

Kedua, kebebasan berkontrak dalam arti formil, yakni sebuah perjanjian dapat diadakan menurut cara yang dikehendaki. Para prinsipnya di sini tidak ada persyaratan apa pun tentang bentuk. Persesuaian kehendak atau kesepakatan antara para pihak saja sudah cukup. Kebebasan berkontrak dalam arti formil sering juga dinamakan prinsip konsensualitas. Dalam rangka inilah untuk mengembangkan hukum yang mengandung unsur refleksi yang dapat mengkompensasi ketidaksamaan kekuasaan dan informasi, menambah operasi sistem desentralisasi melalui cara-cara kompensasi logika hukum, memungkinkan untuk menafsirkan perkembangan 'klausula-klausula umum' tertentu atau standar-standar sebagai 
bukti dari logika refleksif dalam doktrin. Misalnya, walaupun standar seperti 'kejujuran/kepercayaan yang baik' atau 'kebijakan publik' biasanya dipandang sebagai instrumen intervensi judisial substansif, mereka dapat dipandang sebagai alat sosialisasi kontrak yang cukup berbeda dibandingkan secara tradisional sebagai intervensi negara.

Menggunakan standar-standar seperti kejujuran dan kebijakan publik untuk mengkompensasi ketidakadilan, tidak terlepas dari sating berhubungan antara politik, ekonomi, kebudayaan dan hukum, yang refleksif sejauhmana sistem hukum itu sendiri mensimulasi proses-proses pengaturan sosial sendiri.

Hukum Perjanjian/Kontrak, Hukum Tenaga Kerja, dan Hukum Perlindungan Konsumen adalah bentuk-bentuk hukum yang lazim ditemukan dalam negara modern yang mencerminkan pula sebagai hukum-hukum modern, khususnya di bidang Hukum Privat/Perdata, yang semakin memberikan peluang bagi lembaga buk6n negara untuk berperan. Hal tersebut merupakan bagian dari penguatan peran non-negara untuk turut berpartisipasi, turut menentukan isi atau substansi hukum.

Dengan demikian menampakkan pula unsur substansif dan unsur refleksif dalam Hukum Privat/Perdata modern dalam bentuk penguatan mekanisme refleksi tertentu. Hukum Privat modern yang bertolak dari latar belakang dan perkembangannya sejak awal hingga sekarang, terus memperlihatkan perubahan perkembangan dalam bentuk yang berbeda menurut kurun waktu berlakunya hukum itu sendiri.

Perubahan perkembangan ini yang tampak dari suatu kecenderungan untuk mensubstansikan hukum klasik liberal yang formal. saat ini, Kontrol judisial dan peraturan Negara tentang perilaku asosiasi nampak mencapai batas kemampuan mengontrol mereka. Oleh karenanya, pembentukan struktur hukum yang dengan sistematis menguatkan mekanisme refleksi dalam organisasi adalah suatu hal yang penting.

Perubahan perkembangan semacam ini tidak hanya karena menjadi upaya penguatan partisipasi individu dalam konteks partisipasi demokrasi, melainkan sebagai desain dan struktur organisasi yang membuat institusi korporasi, asosiasi semi-publik, media massa, lembaga pendidikan rawan terhadap akibat dari luar. Dengan demikian, 
sebagai fungsi utamanya ialah untuk menggantikan kontrol intervensi dari luar dengan struktur kontrol internal yang efektif.

Hukum substansif yang demikian mengatur fungsi pengawasan dini dari dalam dirinya sebagai kontrol internal dalam mencapai tujuan hukum itu sendiri.

\section{KESIMPULAN}

Perubahan perkembangan dalam Hukum Privat/Perdata modern berkaitan erat dengan perubahan masyarakat dan rezim yang berkuasa, yang semakin menguatnya peran dan partisipasi masyarakat di satu pihak, dan berkurangnya peran negara di lain pihak adalah tidak terlepas dari modernisasi dan demokratisasi dalam negara dan masyarakat itu sendiri. Hukum Kontrak Perjanjian, Hukum Tenaga Kerja, dan Hukum Perlindungan Konsumen mengalami perubahan yang terwujud dari menguatnya fungsi kontrol internal yang menggantikan fungsi kontrol dari luar.

\section{SARAN}

Perubahan masyarakat dan perubahan hukum harus paralel dengan perkembangan dan kebutuhan masyarakat dan hukum itu sendiri. Perubahan perkembangan semacam itu lebih memberikan otonomi internal yang membutuhkan upaya pemahaman atau sosialisasinya karena merupakan hal yang baru dalam suatu negara.

\section{DAFTAR PUSTAKA}

Arief Sidharta, B. (Penerjemah), (2007), Meuwissen Tentang Pengembanan Hukum, Ilmu Hukum, Teori Hukum, dan Filsafat Hukum, Refika Aditama, Bandung.

Huda, Ni'matul, (2005). Negara Hukum, Demokrasi, dan Judicial Review, Ull Press, Yogyakarta.

Ibrahim, Johannes, dan Sewu, Lindawaty, (2004). Hukum Bisnis dalam Persepsi Manusia Modern, Refika Aditama, Bandung.

Salman, Otje, dan Damian, Eddy (ed.), (2006). Konsep-konsep Hukum dalam Pembangunan, Alumni, Bandung.

Syahrani, Riduan, (2004). Rangkuman Intisari Ilmu Hukum, Citra Aditya Bakti, Bandung. 